\title{
Notes and Queries
}

On January 8, 1962 Professor Eilert Ekwall of the University of Lund, Sweden, will celebrate his eighty-fifth birthday. Professor Ekwall's research and publications have covered a wide range in the field of Germanic philology and English studies. His contributions to onomastic scholarship have been numerous and distinguished; among the most recent are Street Names of the City of London (1954) and the fourth edition of his Concise Oxford Dictionary of English Place-Names (1960). To mark the occasion of Professor Ekwall's birthday and to pay tribute to his valuable work, a complete bibliography of his writings is to appear shortly. Compiled by Dr. Olof von Feilitzen of the Royal Library, Stockholm, it will be published by the C. W. K. Gleerup Bokförlag in Lund. The American Name Society joins in extending its warm good wishes and congratulations to Professor Ekwall.

ANS member William Feather, writing in his publication, The William Feather Magazine for July, notes Arthur Minton's series on names in real-estate developments (Names, September and December, 1959; March, 1961), and suggests that someone investigate trends in names given to apartment buildings. His observation is that names that have won distinction elsewhere seem to be favored, and he cites, among others, Essex House, Hampshire House, and Blair House - all within walking distance of each other.

$$
* * *
$$

When ANS Past President Margaret M. Bryant read a paper on "Name Prefixes in Telephone Numbers" at the Society's 1960 meeting, she noted that the telephone company was even then about to abandon the names in favor of a more flexible system using numbers only. Along with the September bills, the New England Telephone and Telegraph company mailed to its subscribers a statement concerning the change, explaining that beginning with the current month's bill, the numbers "... are expressed without the 
usual letters indicating the central office name. Instead of letters, the corresponding figures shown on a telephone dial are used." The company explains further that the new system is necessary for the nationwide direct distance dialing system, grants subscribers a period of grace in which either the old letter names or the new number-combinations may be used, but concludes with the inexorable: "Eventually, letters will disappear altogether from telephone numbers and from telephone dials throughout the United States and Canada."

LYceum, ACademy, REpublic, STate;

NAtional REgent, COlonial VOlunteer;

ALpine CRestview, CHerry ORchard, LYric...

Ave atque vale

$* * *$

A postscript to the discussion of paired names on these pages in the last issue: How do the names of twin cities compare with other twin names? Minnesota's Minneapolis and St. Paul are about as diverse as can be; Duluth and Superior are from the same language family but share little else; Neenah and Menasha (Wisconsin) are both Indian names with abundant nasals, but where are the "leese geese" and alliterations so common in other twin names?

Mr. J. Boddewyn, Assistant Professor of Business Administration at the University of Portland (Oregon) is currently at work on a doctoral dissertation titled "An Environmental Study of the Purpose and Name of Large Industrial Corporations" in which he is especially concerned with the development of corporate names. $\mathrm{He}$ would like to hear from any other $A N S$ members who are interested in the project.

Among many peoples of ages past, it was an accepted fact that evil magic could not be worked on anyone whose right name was not known to the magician; neither could curses be placed effectively on a victim who could conceal his name. Rumpelstiltskin could hold the fairy tale Queen to her sad bargain until she called him 
by his correct name and in so doing stripped away his power. Odysseus replied shrewdly to Polyphemus's question, answering that his name was "No Man" - a pseudonym that ultimately saved his life. In the Volsungasaga Sigurd gives an evasive answer to a similar question from the dying Fafnir because, as a scribal interpolation in prose between the first and second stanzas of the Fáfnismál explains, it was believed in those days that a dying man's curse might have great power if he could call his enemy by name. Maledictions may seem cumbersome in these days of efficient mechanical means of destruction, but it may well be that among the folklore and proverbs that are part of contemporary tradition, there are vestiges of some of these old beliefs in the power of a name. It is still considered very unlucky among conservative Chinese to name a child after a living parent; the theory seems to be that one or the other will suffer greatly and perhaps die as a result. This old American marriage-advice proverb may also fit into the same tradition:

"Change the name and not the letter

Change for worse and not for better."

Let us hope some one has already begun a collection of onomastic folklore and will share it soon with Names readers.

$* * *$

Concluding, but probably inconclusive coincidence: A passenger on the Bergen Steamship Line's SS Leda this summer noted that one of the framed prints on the walls of the corridor leading to the dining salon was a picture of a very attractive swan.

\section{$* * *$}

The Editors would particularly like to urge authors of onomastic items published elsewhere to send reprints or information about their articles, to Miss Duckert for consideration in the Notes and Queries column. This is the best way we can devise to bring such activities to the attention of Names readers who might miss interesting material in its place of original publication. 
In order to make sure that the PMLA bibliography coverage on onomastics includes a thorough coverage of the production of $A N S$ members, including articles published in Names, it is urged that authors send reprints of all their published works for a given year to the MLA Bibliographer, Dr. Paul A. Brown, Temple University, Philadelphia 22, Pennsylvania.

\section{TENTH ANNIVERSARY VOLUME OF NAMES}

The journal $N A M E S$, celebrating its tenth anniversary in 1962, invites papers, preferably shorter contributions (up to eight printed pages each, with some exceptions for longer articles), for its March and June 1962 issues from members as well as friends of the American Name Society and from fellow onomatologists abroad. The tenth volume, for the year 1962, containing 320 pages, will be larger than any previous volume.

The Editor

\section{THE AMERICAN NAME SOCIETY ANNUAL MEETING PROGRAM}

Friday and Saturday, December 29th and 30th, 1961

All meetings except the Annual Dinner

will be held in Room 18, Palmer House, Chicago, Illinois

Jack A. Dabbs, Chairman, Program Committee; Elsdon C. Smith, Chairman, Committee on Local Arrangements. Members of Local Arrangements Committee: Helen Carlson and I. J. Gelb.

Friday, December 29, 6:00 p.m.

Annual Dinner

Room 17, Palmer House, Chicago, Illinois

Jack A. Dabbs, A. \& M. College of Texas, presiding.

Address

John B. Tuttle, Standard Oil Co. of New Jersey, "Names in Oil." 